\title{
COMMON AGRUCULTURAL POLICY AND THE SUSTENABLE DEVELOPMENT OF FARMS IN POLAND AFTER ACCESSION TO THE EUROPEAN UNION
}

\author{
Katarzyna SMĘDZIK-AMBROŻY ${ }^{1}$ \\ Sebastian STEPIEN' ${ }^{2}$ \\ Marta GUTH
}

\begin{abstract}
The purpose of the article was to determine the impact of Common Agricultural Policy (CAP) instruments on the sustainability of agricultural holdings in Poland in 2004-2014. For this purpose, a panel analysis was used based on farm accountancy data (FADN). The first part of the study discusses the importance of sustainable development of agriculture as a strategic goal of the European Union, emphasizing economic and environmental dimensions as priorities of sustainable development of agriculture. The next section of the study shows the evolution of the Common Agricultural Policy of the EU and the change of its instruments to create sustainable growth in agriculture. The last part of the study evaluates the impact of individual agricultural policy instruments on the sustainable development of the agricultural sector in Poland in 2004-2014. In order to determine the direction and strength of the impact of CAP tools a panel analysis was used. It has been shown that agri-environmental subsidies are an instrument that positively influences the economic and environmental sustainability of farms in Poland. In addition, it has been proven that replacing subsidies for agricultural production with single area payments does not affect the increase in the sustainability of agriculture in Poland, although this process is perceived as the main factor creating sustainable development. In relation to this, it can be concluded that agri-environmental subsidies are the most beneficial instrument in the pursuit of increasing the sustainability of agriculture in Poland.
\end{abstract}

Keywords: sustainable development, Polish farms, Common Agricultural Policy, influence

JEL codes: H2, Q12, Q18, Q56

\section{Introduction}

The influence of agricultural policy on the sustainable development of agriculture results from the concept of induced agricultural development formulated by Y. Hayami and V.W. Ruttana (1985). They found that agriculture generates too weak internal forces so that they could trigger an upward process and keep it in a state of dynamic equilibrium, so its development requires impulses from outside or exogenous stimuli (Hayami and Ruttan, 1985; Parzonko, 2013). Agricultural policy plays the role of such a stimulator. Also R. E. Lucas and S. T. Sargent proved that economic entities and people flexibly adapt their activities and expectations to state policy, using all the benefits resulting from it (Wigier, 2013). The above statements show the possibility of using the policy as a stimulator of sustainable development. This is also confirmed by the opinions of C. Rodríguez Morilla, G. L. DíazSalazarba and M. Alejandro Cardenetec (Rodríguez Morilla et al., 2007). According to the authors, policy can minimize the negative impact of given sectors on the environment if its impact is aimed at achieving this goal. In this way, it contributes to sustainable economic development. This view is shared by many authors studying the impact of the EU Common Agricultural Policy on the level of

\footnotetext{
${ }^{1}$ Poznań University of Economics and Business, tel. +48 6185430 21, e-mail: katarzyna.smedzik-ambrozy@ue.poznan.pl ${ }^{2}$ Poznań University of Economics and Business, tel. +48 $61 \quad 854 \quad 30 \quad 21$ or $+48 \quad 696 \quad 411 \quad 391$, e-mail: sebastian.stepien@ue.poznan.pl

${ }^{3}$ Poznań University of Economics and Business, tel. +48 6185430 21, e-mail: marta.guth@ue.poznan.pl
}

DOI: 10.29302/oeconomica.2018.20.2.1 
sustainability of European agriculture. For example, according to J. Wilkin, "sustainable development can only be achieved by properly combining public policy (national and EU) with regulated market mechanisms" (Wilkin, 2011). In turn J. St. Clock says that "the European Agriculture Model (EMR) sets the direction of EU agriculture development, through CAP solutions such as: cross-compliance, greening, animal welfare, Rural Development Programme including agri-environmental program" (Zegar, 2014).

Sustainable development is a concept that assumes a close relationship between economic growth and the natural environment. The definition of sustainable development covers a number of areas and underlines the idea of sustainability of environmental protection, economic and social development within the limits of available global natural resources (Bartelmus, 1999). This is not a new term because it was first used in 1987 by the World Commission on Environment and Development known as the Brundtland Commission. The concept itself was clarified already in the 1970s. The report "Our Common Future" defines sustainable development as: "satisfying the present needs, without jeopardizing the ability of future generations to meet their needs" (Asef, 2005; Green, 2012; Board on Sustainable Development..., 1999; Czyżewski and Brelik, 2014; Brelik 2010). In 1997, sustainable development became a major challenge for the EU and was included in the Treaty of Amsterdam as the overarching objective of EU policy (European Commission, 1997). In connection with the above, the aim of the article was to determine the impact of CAP instruments on the sustainability of agricultural holdings in Poland in 2004-2014. Methodological remarks will be presented in a separate part of the publication.

\section{Agriculture in the context of sustainable development}

Defining sustainable agriculture, just like the concept of sustainable development, takes place through the prism of three basic orders: environmental, economic and social. In the first of these, the implementation of agricultural production is underlined, which would not threaten, and even enable the preservation of the natural environment in good condition. The agricultural sector's ability to provide public goods, such as protecting the rural landscape and ensuring the welfare of plants and animals, which is necessary for the implementation of tourist functions by farms located in rural areas, is the foreground here (Czyżewski and Czyżewski, 2015; Brelik, 2015; Przezbórska-Skobiej, 2014). In defining the next element, economic one, the most important is to provide agricultural income that allows a fair standard of living. This is a microeconomic approach. However, the macroeconomic definitions emphasize the relationship between economically sustainable agriculture and food security, and hence its ability to produce the right amount and quality of food products required by consumers at prices that they accept (Clock, 2005).

In the case of the social aspect, the contribution of sustainable agriculture to maintaining and developing cultural values and its ability to maintain and create new jobs as well as to secure the duration and functioning of social institutions in rural areas is emphasized. Social indicators refer to such issues as: the utilization of agricultural labor resources, the contribution of agriculture to maintaining and developing the economic and social viability of rural areas, the share of people employed in agriculture to the total employed in the economy, employment in agriculture per 100 ha, unemployment rate, labor productivity (Matuszczak, 2013). Indicators of the level of social sustainability point to the difficulty in preserving the separate nature of environmental and economic aspect from the social one. Environmental and economic elements influence the achievement of social sustainability. In connection with the above, the study focuses on the economic and environmental dimension, assuming that the higher the level of economic and environmental sustainability of an agricultural holding, the higher its sustainability in the social context.

\section{Common Agricultural Policy towards implementation of sustainable development - literature review}

Previous experiences of the EU's Common Agricultural Policy allow to distinguish two subperiods of its functioning. The first sub-period of the CAP, from the introduction of intervention tools 
in 1962 to the MacSharry reform in 1991, was a phase of pro-supply policy and its aim was to solve the lack of food in Europe after World War II (for more see Ruttan, 2005). This goal was achieved in a relatively short time, and over the years, overproduction of agricultural raw materials became a problem ${ }^{4}$, with reducing the quality of natural resources at the same time. The striving to limit surpluses has become the premise of the so-called Mansholt plan (name of the EU Commissioner for Agriculture), introduced in 1972. It was the first formalized attempt to influence the model of European agriculture towards its extensification. However, the proposed instruments were insufficient, which highlighted the need for a more radical reform to reduce the intensity of European agriculture (Czyżewski and Matuszczak, 2013).

Only a thorough reform of the CAP in 1991 (the so-called MacSharry reform, the Commissioner for Agriculture) and related new support principles made the EU agricultural policy evolving towards the policy of creating demand and income support, putting more and more pressure for economic and environmental sustainability. Quoting from B. Czyżewski and A. Matuszczak, "since the beginning till MasSharry's reform, the Common Agricultural Policy has not been conducive to the sustainable development of agriculture, both in the EU as a whole and in individual agricultural regions. On the contrary, there was a deepening of the disproportions, especially developmental ones, and in the resource and production structures between and within regions. (...) Concentration of transfers in the strongest and largest farms resulted in social and environmental diversity." (Czyżewski and Matuszczak, 2013). The described problems were to be overcome by successive reforms, presented in tables no. 1. From today's perspective, it can be concluded that a large part of the postulates were achieved. EU agriculture produces high quality food, takes care about the environment and rural areas, contributes to the modernization of farms and raises their incomes, limits (although at a slow rate) income differences between large and small farms etc. (Czyżewski and Stępień, 2018).

\section{Research methodology}

The criteria for determining the impact of individual farms on the quality of natural capital include: 1) share of cereals in the crop structure, 2) number of crop groups, 3) index of arable land covered with vegetation in winter, 4) animal stock density in livestock units (LU) per ha of UAA, 5) management of organic matter in soil. The number of criteria met by the farm determines its environmental sustainability (Zagar, 2014; Wrzaszcz, 2012; Majewski, 2008; Kuś and Kopiński, 2011). In terms of economic element, income from agricultural activity was used as a synthetic measure of farm sustainability. The parity relation of agricultural income to the average salary in the national economy is considered desirable (Wrzaszcz, 2012; Matuszczak and Smędzik-Ambroży, 2013). The analyzes were based on standard data from representative farms conducting accounting system FADN (Farm Accountancy Data Network) and covered individual voivodships in Poland in 2004-2014. In order to determine the direction and strength of the impact of individual CAP instruments on the economic and environmental sustainability of these farms, a panel analysis was used.

In reference to the models assessing the impact of individual CAP instruments on the economic sustainability of agricultural holdings, the ratio of farm income in relation to the average gross salary in a given voivodship was assumed to be a dependent variable. In the case of models used to assess the impact of individual CAP instruments on the environmental sustainability of farms, the average value of the environmental sustainability criteria was adopted as a dependent variable. These criteria included three mentioned above:

- share of cereals in the crop structure,

- number of crop groups,

- animal stock density in livestock unit (LU) per ha of UAA.

In the group of the above criteria there were no criteria related to the management of organic

\footnotetext{
${ }^{4}$ In response to this problem, production quoting was introduced in the 1980s. This instrument imposed the upper limit for the production of certain agricultural products (milk, sugar), entitling farmers to sell the products at intervention price (see Judzińska and Łopaciuk, 2011).
} 
matter in soil and arable land covered with vegetation in winter, due to the lack of such data in the FADN system. While in relation to the others, the higher the values of independent variables in both models, the higher the level of economic and environmental sustainability of the analyzed farms.

\begin{tabular}{|c|c|c|}
\hline \multicolumn{3}{|c|}{ Reforms of the Common Agricultural Policy towards a sustainable agriculture model } \\
\hline Year & Reform & Main purposes of reform in direction to sustainability \\
\hline 1992 & $\begin{array}{l}\text { MacSharry's } \\
\text { reform }\end{array}$ & $\begin{array}{l}\text { - reduction of intervention prices (cereals, beef and butter), and } \\
\text { in return introduction of compensation payments (later called } \\
\text { direct payments), } \\
\text { - creating a set-aside system for agricultural land, } \\
\text { - an early retirement system for farmers, } \\
\text { - environmental and afforestation payments, }\end{array}$ \\
\hline 1999 & Agenda 2000 & $\begin{array}{l}\text { - further reduction of intervention prices and an increase in the } \\
\text { level of direct payments, } \\
\text { - creating the second pillar of the CAP for rural development, } \\
\text { - support for areas with less favorable natural conditions, }\end{array}$ \\
\hline 2003 & Luxemburg reform & $\begin{array}{l}\text { partial decoupling } \text { of direct payments from production (SPS }^{5} \\
\text { system }^{6} \text { ), } \\
\text { introduction of cross-compliance rules (regarding, among } \\
\text { others maximum fertilization and animal husbandry } \\
\text { requirements) and modulation of direct payments (reduction } \\
\text { for bigger farmers), } \\
\text { - increasing funds for rural development, }\end{array}$ \\
\hline 2005 & $\begin{array}{l}\text { Reform of tobacco, } \\
\text { honey, oil and } \\
\text { cotton sector }\end{array}$ & $\begin{array}{l}\text { - some or all of the payments related to production included in } \\
\text { the SPS system; }\end{array}$ \\
\hline 2006 & $\begin{array}{l}\text { Reform of sugar } \\
\text { sector }\end{array}$ & $\begin{array}{l}\text { - limiting interventions and introducing compensation for } \\
\text { excluding of sugar production, easing barriers in importing raw } \\
\text { materials; }\end{array}$ \\
\hline 2007 & $\begin{array}{l}\text { Reform of fruits } \\
\text { and vegetables } \\
\text { sector }\end{array}$ & $\begin{array}{l}\text { - } \text { support for processors under SPS } \\
\text { reduction of export subsidies, }\end{array}$ \\
\hline 2008 & $\begin{array}{l}\text { Health check (mid- } \\
\text { term review of the } \\
\text { CAP budget for } \\
\text { 2007-2013) }\end{array}$ & $\begin{array}{l}\text { - } \text { further limiting of market intervention, } \\
\text { - } \text { extension of decoupling and modulation, } \\
\text { - } \text { nuspension of compulsory set-aside, } \\
\text { new functions in CAP tools: climate change, risk management. }\end{array}$ \\
\hline 2013 & Ciolos' reform & $\begin{array}{l}\text { - introduction of proecological payment - "greening" of the } \\
\text { CAP (payment depends on environmental actions), } \\
\text { - greater flexibility of countries in the implementation of the } \\
\text { rural development policy, }\end{array}$ \\
\hline
\end{tabular}

\footnotetext{
${ }^{5}$ Direct payments were separated from the structure and volume of agricultural production, thus breaking the relationship between the amount of support and what and how much the farmer produced. The aim was to improve the allocation of production resources and increase the market orientation of producers to make them more flexible in terms of market prices and supply fluctuations.

6 The Single Payment Scheme (SPS) was used in the EU-15 and in Croatia, Malta and Slovenia. Payments were granted to the farmer on the basis of his rights to the cultivated land. In the new Member States, the SAPS - Single Area Payment Scheme - was introduced, in which the use of agricultural land decides about granting support to farmers.
} 
new support programs for small farms.

Source: Marcinkowski et al., 2011; Czyżewski and Stępień, 2014

Independent variables, both in the case of the model determining the impact of CAP instruments on farm sustainability in the economic and environmental aspect, include the value of financial support for specific CAP instruments per 100 ha of UAA of a given farm. Therefore, these were the following values: subsidies on production (coupled payments $\mathrm{CP}$ ), single area payments (decoupled payments DP), other rural development payments (RDP), agri-environmental payments (AEP), investment payments (IP), subsidies for less-favored areas (LFA). The estimated models for sustainability in the economic and environmental context were:

$$
Y=b_{0}+b_{1} C P+b_{2} D P+b_{3} R D P+b_{4} A E P+b_{5} I P+b_{6} L F A
$$

The co-linearity of the variables was evaluated on the basis of variance inflation factors (VIF). Since none of the variables exceeded the critical value VIF $=10$, the inference was based on the estimated models. The Doornik-Hansen $\mathrm{chi}^{2}$ test was used to assess the compatibility of the distribution of residues with the normal distribution. A "step back" regression was performed to eliminate nonsignificant variables. The problem of heteroscedasticity caused the resignation from estimation by classical panel methods for fixed and random effects. An estimation of weighted least squares was therefore carried out. Due to small attempts to eliminate the heteroscedasticity problem, it was impossible to apply the so-called resistant errors (robust) (Stawiński, 2017; Maddala, 2013). The number of observations was 176 , which resulted from the number of voivodships (16) and the time range of analyzes (11 years). Statistically significant function parameters allowed to conclude on the impact of a given CAP instrument on the economic and environmental sustainability of representative FADN farms in the years 2004-2014.

\section{Results and discussion}

The results of the analyzes showed a positive effect of coupled subsidies (CP) on the economic sustainability of FADN farms in 2004-2014. However, the impact of these subsidies on the environmental sustainability of agriculture in Poland has not been demonstrated. With reference to the value of single area (decoupled) payments (DP), the negative impact of these subsidies on the environmental sustainability of FADN farms was indicated. Single area payment system (SAPS) operating in Poland is a function of the area of farms and causes the capture of a large part of subsidies by large farms, which leads to excessive concentration of land. The results of the research may justify the state intervention on the agricultural land market in order to limit the domination of large farms over family households. A similar view is presented by R. Marks-Bielska, R. Kisiel and W. Lizińska (2017). Such an intervention is also justified from the point of view of ensuring the environmental sustainability of agriculture. On the other hand, in the analyzed period, the impact of SAPS payments on the economic sustainability of agricultural holdings in Poland was statistically insignificant. At this point it is worth recalling that in these studies, the measure of the level of economic sustainability was the ratio of farm income in relation to the average gross salary in a given voivodship. Therefore, it does not contradict other studies showing the positive impact of area payments on the economic results of agricultural holdings in EU countries (Sobczyński, 2008; Drygas, 2010; Stępień et al., 2017). The results only show that decoupled direct payments did not significantly affect the ratio of farm income to the average gross salary in a given voivodship in Poland. In addition, it has been proved that the replacement of coupled subsidies for production by decoupled single area payments did not reduce the adverse impact of agricultural production on the natural environment of rural areas. The proof is the negative value of the coefficient with the variable "single area payments - decoupled payments DP" (see table no. 2).

A positive impact on both the economic and environmental sustainability of Polish FADN 
farms in 2004-2014 was demonstrated in the case of agri-environmental subsidies (AEP). This confirms the beneficial impact of activities financed from these programs on the natural conditions of rural areas, as well as the economic situation of agriculture after 2004. Therefore, it can be said that agri-environmental subsidies favor the growth of environmental sustainability (which should not come as a surprise in relation to this program), but also improve the income situation of farms in relation to non-agricultural incomes. From the point of view of the sustainable agriculture model, this is the optimal state. This highlights the legitimacy of institutional actions for financial gratification of agricultural producers for practices that take into account the quality of natural resources (see Gasber and Nolten, 2007). Without an appropriate financial stimulus, action for nature could be overlooked by farmers. According to K. Brodzińska (2012), only every tenth participant (farmer) joined this program due to environmental benefits.

Table 2.

Impact of individual CAP instruments on the economic and environmental sustainability of representative FADN farms in 2004-2014 - results of panel model estimation*

\begin{tabular}{|l|l|l|}
\hline Variable & $\begin{array}{l}\text { Economic } \\
\text { sustainability }\end{array}$ & $\begin{array}{l}\text { Environmental } \\
\text { sustainability }\end{array}$ \\
\hline $\begin{array}{l}\text { CP (value of coupled payments per 100 ha } \\
\text { of UAA) }\end{array}$ & $\begin{array}{l}0,000575^{* * *} \\
(0,0002)\end{array}$ & \\
\hline $\begin{array}{l}\text { DP (value of decoupled single area } \\
\text { payments per 100 ha of UAA) }\end{array}$ & $\begin{array}{c}-1,73616 \mathrm{e}^{-06} * * \\
\left(8,6518 \mathrm{e}^{-07}\right)\end{array}$ \\
\hline $\begin{array}{l}\text { RDP (value of rural development } \\
\text { payments per 100 ha of UAA) }\end{array}$ & $\begin{array}{l}-0,007597 * * * \\
(0,0010)\end{array}$ & $\begin{array}{c}3,88702 \mathrm{e}^{-05} * * * \\
\left(5,9944^{\mathrm{e}-06}\right)\end{array}$ \\
\hline $\begin{array}{l}\text { AEP (value of agri-environmental } \\
\text { payments per 100 ha of UAA) }\end{array}$ & $\begin{array}{l}0,002910^{* * *} \\
(0,0006)\end{array}$ & $\begin{array}{c}1,33171 \mathrm{e}^{-05 * * *} \\
\left(3,1438 \mathrm{e}^{-06}\right)\end{array}$ \\
\hline $\begin{array}{l}\text { IP (value of investment payments per 100 } \\
\text { ha of UAA) }\end{array}$ & $\begin{array}{l}-0,001513 * * * \\
(0,0004)\end{array}$ & $\begin{array}{l}6,1409 \mathrm{e}^{-06} * * \\
\left(2,8220 \mathrm{e}^{-06}\right)\end{array}$ \\
\hline $\begin{array}{l}\text { LFA (payments for less favourable areas } \\
\text { per 100 ha UR) }\end{array}$ & $\begin{array}{l}-0,000943 * * \\
(0,0004)\end{array}$ & $\begin{array}{c}1,3369 \\
(0,0335)\end{array}$ \\
\hline Constant & $\begin{array}{l}122,060 * * * \\
(5,8502)\end{array}$ & $\begin{array}{c}0,3799 \\
\mathrm{p}<0,00\end{array}$ \\
\hline F statistic & $\begin{array}{l}15,31722 \\
\mathrm{p}<0,00\end{array}$ \\
\hline
\end{tabular}

* standard errors of parameters are given in brackets, *** means significance at the level of $\mathrm{p}<0.01$; ** means significance at the level of $\mathrm{p}<0.05$; * means significance at the level of $\mathrm{p}<0.10$; lack of value in the cell means that the given variable was irrelevant.

Source: Own calculation based on FADN database,

http://ec.europa.eu/agriculture/rica/database/database_en.cfm (access date: 20.10.2018).

A positive impact on the environmental sustainability of agriculture was also obtained in the case of subsidies to LFA areas. However, in relation to the economic sustainability of farms, the impact of these subsidies was unfavourable (see table no. 2). These dependencies are not surprising, because the more LFA areas in a structure of land, the less favourable conditions for agricultural production. This, in turn, implied relatively worse economic results of the agricultural sector and translated into less beneficial economic situation of farmers from these regions compared to farms from other areas (without LFA).

The unfavourable impact on the economic sustainability of farms in Poland was also obtained in the case of subsidies for rural development (RDP) and subsidies for investments (IP). It can be assumed that the results of the analysis revealed the phenomenon of financing investments with external capital, and, as a result, the financial outcome of farm was burdened with repayment of credit 
instalments. Thus, it can be said that in the years 2004-2014, the analysed farms were in the phase of financing investments with credits and loans, which lowered their profitability and economic balance in the short time. In the long time, however, such an operation may lead to an increase in production potential, and consequently to improving of economic results.

\section{Conclusions}

The article shows that in 2004-2014 some of the CAP instruments contributed to the sustainable development of agriculture in Poland in environmental and economic aspect. Payments from agricultural policy affected both the economic situation of agriculture in relation to other sectors and the natural conditions of rural areas. However, the strength and direction of the impact of CAP instruments on the economic and environmental sustainability of farms in Poland differed among themselves. This is evidenced by data achieved from FADN farms. In the analysed period, agrienvironmental subsidies had a beneficial effect on the economic and environmental sustainability of agricultural holdings, thus the significance of this intervention policy instrument in striving for sustainable development of agriculture in Poland was the most important. It was also proved that the replacement of payments for agricultural production (coupled payments) with single area payments (decoupled payments) did not result in an increase in the sustainability of farms in Poland. What is more, it led to its reduction in environmental terms. Finally, the calculations showed that as a result of financing investments and other rural development programs through external capital, the impact of these support tools on the sustainability of agriculture was negative in the short term (but in the longterm positive relation between the analyzed variables could be observed). The article is a leaven for further work on the sustainability of the agricultural sector, both at the national and EU level. A thorough analysis of the impact of the CAP on agriculture will create a recommendation for future reforms of agricultural policy in the European Union.

\section{Acknowledgment}

The paper was written as a part of research project titled „Determinants of food security and sustainable development of small farms in Poland against the background of the European Union regions", financed by the National Science Centre in Poland (agreement no. 2016/21/B/HS4/00653).

\section{References}

1. Asefa S., 2005. Economics of Sustainable Development. Kalamazoo, Upjohn Institute for Employment Research.

2. Bartelmus P., 1999. Greening the National Accounts - Approach and Policy Use, DESA Discussion Paper, no 3.

3. Board on Sustainable Development, Policy Division, National Research Counsil, 1999. Our Common Jurney: A Transition Toward Sustainability. Washington, National Academies Press, p. 21.

4. Brelik A., 2010. Zrównoważony rozwój społeczno-gospodarczy a rozwój agroturystyki. Roczniki Ekonomiczne Kujawsko-Pomorskiej Szkoły Wyższej w Bydgoszczy, no. 3.

5. Brelik A., 2015. Dobra publiczne na obszarach wiejskich jako czynnik rozwoju działalności agroturystycznej na Pomorzu Zachodnim. Warsaw, PWN.

6. Brodzińska K., 2012. Świadomość ekologiczna rolników a praktyka gospodarowania. Roczniki Naukowe Stowarzyszenia Ekonomistów Rolnictwa i Agrobiznesu, no. XIV, vol. 5, p. 37.

7. Czyżewski B., Brelik A., 2014. Sustainable development of agriculture-case of Poland. Roczniki Naukowe Stowarzyszenia Ekonomistów Rolnictwa i Agrobiznesu, no. XVI, vol. 2.

8. Czyżewski B., Matuszczak A., 2013. Wspólna polityka rolna $w$ kształtowaniu zrównoważonego rozwoju rolnictwa $w$ aspekcie dostosowań regionalnych. Roczniki Naukowe Stowarzyszenia Ekonomistów Rolnictwa i Agrobiznesu, no. XV, vol. 3, p. 229. 
9. Czyżewski A., Czyżewski B., 2015. Ziemia i jej renty w nowym paradygmacie rozwoju rolnictwa. In: A. Czyżewski, B. Klepacki (eds.), Problemy rozwoju rolnictwa i gospodarki żywnościowej $w$ pierwszej dekadzie członkostwa Polski w Unii Europejskiej, Warsaw, PWE, pp. 27-41.

10. Czyżewski, A., Stępień, S., 2017. Nowe uwarunkowania ekonomiczne wspólnej polityki rolnej (WPR) Unii Europejskiej. Ekonomista, no. 6, pp. 675-697.

11. Drygas M., 2010. Wplyw doptat bezpośrednich w ramach Wspólnej Polityki Rolnej 2004-2006 i 2007-2013 na przeksztatcenia obszarów wiejskich w województwie pomorskim (ekspertyza wykonana na zamówienie Urzędu Marszałkowskiego w Gdańsku). Warsaw, IRWiR PAN.

12. Green L. M., Espinal L., Traversa E., Amis E. J., 2012. Materials for sustainable development. MRS Bulletin, no. 37, p. 303.

13. Gasber M. A., Nolten R., 2007. Participative conceptions to integrate local farmers in rural planning processes. Economic Science for Rural Development, no. 12.

14. Hayami Y., Ruttan V. W., 1985. Agricultural Development. An International Perspective (2d edition). Baltimore, John Hopkins University Press.

15. Judzińska A., Łopaciuk W., 2011. Wpływ Wspólnej Polityki Rolnej na rolnictwo. Warsaw, IERiGŻPIB, pp. 20-23.

16. European Commission, 1997. European Union Treaty of Amsterdam. Amsterdam, http://europa.eu/eu-law/decisionmaking/treaties/pdf/treaty_of_amsterdam/treaty_of_amsterdam_en.pdf (access date: 16.09.2017).

17. FADN database, http://ec.europa.eu/agriculture/rica/database/database_en.cfm (access date: 20.10.2018).

18. Kuś J., Kopiński J., 2011. Gospodarowanie glebowa materia organiczna $w$ kontekście zmian zachodzacych $w$ polskim rolnictwie. In: J.St. Zegar (ed.), Z badań nad rolnictwem społecznie zrównoważonym $n r$ 11, Warsaw, IERiGŻ-PIB.

19. Kuś J., Matyka M., 2014. Zmiany organizacyjne w polskim rolnictwie w ostatnim 10-leciu na tle rolnictwa UE. Zagadnienia Ekonomiki Rolnej, no. 4(2014).

20. Kusz D., 2013. Inwestycje produkcyjne w gospodarstwach rolniczych korzystajacych ze wsparcia finansowego Unii Europejskiej. Zeszyty Naukowe SGGW - Ekonomika i Organizacja Gospodarki Żywnościowej, no. 103.

21. Marcinkowski M., Narojczyk S., Stępień S., 2011. Kierunki zmian funkcjonowania wybranych rynków rolnych w kontekście ewolucji wspólnej polityki rolnej UE. In: A. Czyżewski, S. Stępień (eds.), Rozwój rolnictwa i obszarów wiejskich $w$ warunkach ewolucji WPR: wybrane problemy, Bydgoszcz, KPSW.

22. Marks-Bielska R., Kisiel R., Lizińska W., 2017. Uwarunkowania polityki polskiego rzadu odnośnie rynku ziemi rolniczej $w$ kontekście zakończenia okresu przejściowego nabywania nieruchomości rolnych przez cudzoziemców. Problemy Drobnych Gospodarstw Rolnych, no. 3.

23. Maddala G. S., 2013. Ekonometria. Warsaw, PWN, pp. 241-270.

24. Majewski E., 2008. Trwaty rozwój in trwate rolnictwo - teoria i praktyka gospodarstw rolniczych. Warsaw, SGGW.

25. Matuszczak A., (2013. Wskaźniki zrównoważonego rozwoju rolnictwa: przesłanki teoretyczne $i$ propozycja pomiaru w regionach UE. Wieś i Rolnictwo, no. 1(158), p. 111.

26. Matuszczak A., Smędzik-Ambroży K., 2013. Próba ocen wspótzależności pomiędzy zrównoważeniem środowiskowym a wynikami ekonomicznymi gospodarstw rolnych na przykładzie regionu Wielkopolska $i$ Ślask. In: J. St. Zegar (ed.), Z badań nad rolnictwem społecznie zrównoważonym $\mathrm{nr}$ 19, Warsaw, IERiGŻ-PIB.

27. Parzonko A., 2013. Koncepcja rozwoju sektora mlecznego w UE, proponowane instrumenty jej wdrożenia $i$ przewidywane skutki po 2014 roku. Zeszyty Naukowe SGGW - Ekonomika i Organizacja Gospodarki Żywnościowej, no. 101, p. 68.

28. Poczta W., Pawlak K., Kiryluk-Dryjska E., Siemiński P., 2007. Perspektywy polskich gospodarstw rolnych w europejskim modelu rolnictwa. Roczniki Naukowe Stowarzyszenia Ekonomistów Rolnych i Agrobiznesu, no. IX, vol. 2. 
29. Przezbórska-Skobiej L., 2014. Obszary wiejskie i rolnictwo jako źródło dóbr publicznych $w$ agroturystyce. Zeszyty Naukowe SGGW - Problemy Rolnictwa Światowego, no. 14, vol. 2, pp. 194-202.

30. Rodríguez Morillaa C., Díaz-Salazarb G. L., Alejandro Cardenetec M., 2007. Economic and environmental efficiency using a social accounting matrix. Ecological Economics, no. 60, p. 779.

31. Ruttan V. W., 2005. Productivity Growth in Word Agriculture: Sources and Constraint. In: S. Asefa (ed.), Economics of Sustainable Development, Kalamazoo, Upjohn Institute for Employment Research, pp. 65-99.

32. Sobczyński T., 2008. Zmiany udzialu doplat $w$ dochodach gospodarstw rolniczych UE $w$ latach 1989-2005. In: D. Kopycińska (ed.), Polityka Unii Europejskiej, Szczecin, Uniwersytet Szczeciński.

33. Stawiński P., 2017. Asymptotyka $i$ statystyczne podstawy regresji. coin.wne.uw.edu.pl/pstrawinski/notatki/asymptotyka.pdf (access date: 12.09.2018).

34. Stanisz A., 2007. Przystepny kurs statystyki z zastosowaniem STATISTICA PL na przyktadach z medycyny, tom 1. Statystyki podstawowe. Kraków, StatSoft.

35. Stępień, S., Czyżewski, A., 2014. Budget of the EU and Common Agricultural Policy for 20142020 un the light of the polish interests. MANAGEMENT, no. 1, pp. 473-478.

36. Stępień, S., Smędzik-Ambroży, K., Guth, M., 2017. Oddziaływanie Wspólnej Polityki Rolnej na zrównoważenie ekonomiczno-społeczne gospodarstw rolnych na przykładzie Polski. Wieś i Rolnictwo, no. 4(177), pp. 39-58.

37. Swinton S. M., 2005. Too poor to be stewards? Rural Poverty and Sustainable Natural Source Management. In: S. Asefa (ed.), Economics of Sustainable Development, Kalamazoo, Upjohn Institute for Employment Research.

38. Wigier M., 2013. Model rozwoju rolnictwa polskiego $w$ świetle efektów realizacji WPR. Zagadnienia Ekonomiki Rolnej, no. 1.

39. Wilkin J., 2011. Wielofunkcyjność wsi i rolnictwa a rozwój zrównoważony. Wieś i Rolnictwo, no. 4 (153), pp. 24, 30.

40. Wrzaszcz W,. 2012b. Poziom zrównoważenia indywidualnych gospodarstw rolnych $w$ Polsce. Studia i Monografie no. 155. Warsaw, IERiGŻ-PIB, p. 79.

41. Zegar J.St., 2005. Koncepcja badań nad rolnictwem społecznie zrównoważonym nr 11. Warsaw, IERiGŻ-PIB.

42. Zegar J.St., 2014. Z badań nad rolnictwem społecznie zrównoważonym (27). Alternatywne formy rolnictwa $w$ strategii rozwoju sektora rolno-żywnościowego i obszarów wiejskich (Synteza). Warsaw, IERiGŻ, p. 214. 